\title{
Game Study on Host City Behavior in Enclave Economy
}

\author{
Xiang Wanhong ${ }^{1,2}$ \\ 1 School of Management \\ Wuhan University of Technology \\ Wuhan, P.R.China \\ 2 Office of Beibu Gulf Economic Zone and Opening and \\ Cooperation with ASEAN of Guangxi Zhuang \\ Autonomous Region \\ Nanning, P.R.China \\ E-mail: 46779815@qq.com
}

\author{
Feng Yanfei \\ School of Management \\ Wuhan University of Technology \\ Wuhan, P.R.China \\ E-mail: hsfyf3012@163.com
}

\begin{abstract}
Enclave economy is a brand new regional economic development model that is chosen by different administrative regions for economic cooperation. It is crucial and efficient in solving difficulties of land bottleneck and institutional barrier, complementing advantages between two places and promoting regional coordinated development. Due to similar geographic condition, industrial base and the same stage of development, there is inevitable the fierce competition among the host cities in China's central and western regions to develop enclave economy. In view of this, this paper builds the game model of two-city developing enclave economy in view of comparative advantage and preferential policy. Result shows: the city with the comparative advantage will gain more profit, so as the city cooperation, etc. On the basis of this, enclave economy based on the advantages must be developed. What's more, reasonable division coordination mechanism must be set up to avoid vicious competition.
\end{abstract}

Keywords- Comparative Advantage;Preferential Policy; Enclave Economy;Game Model

\section{INTRODUCTION}

Enclave economy refers to an economy development model that is built between two cities belong to different administrative regions: city a (also called investing city) constructs an industrial park in city b (also called host city), both parties involved establish scientific benefit sharing and management mechanisms to achieve a mutual beneficial and win-win economic cooperation. Enclave economy is crucial and efficient in solving difficulties of land bottleneck and institutional barrier, complementing advantages between two places and promoting regional coordinated development. Therefore, enclave economy has become a new way to promote cooperation and communication in the Midwestern underdeveloped region and the eastern developed region of China, which is highly regarded by all parties.
To facilitate the research, the host cities are the inner cities of one province or economic zone and urban agglomeration in China's central and western regions in this paper. The host cities have similar location conditions and industrial bases. To pursue of the maximum profits, the host cities are likely to face fierce competitions when they develop enclave economy. Such fierce internal competitions will hinder economy development. On that basis, this paper firstly analyzes the competition that generates between the host cities due to their similar role and functions in attracting investment and projects, and offers proposals that are based on the game theory research conclusion by establishing an enclave economy game model to compare two-city comparative advantage and preferential policy.

\section{LITERATURE REVIEW}

Enclave is a special cultural and geographical phenomenon. It originally refers to a special geographical entity that locates in a country but actually affiliated with another country. The term of Enclave Economy first appeared in 2004, Chinese scholars quoted the word "enclave" to economic field when they researched on industrial transfer. About enclave economy, foreign scholars focused on three aspects: ethnic enclave economy(Min Zhou 2010, Kathleen A 2001, Edward Iwata 2007, Peter S Li 2004, Heike Christine Alberts 2003), resource enclave economy (Joseph E Mbaiwa 2005), FDI enclave economy (Kevin P Gallagher 2007).

While almost all Chinese scholars focused on the domestic characteristic enclave economy pattern. Li Junyang (2006), Feng Yunting (2013), Li Yu (2007), Mao Baobin (2014) usually paid attention to its theory source, connotation and condition, basic feature, development pattern, significance and various regional practical experience, etc. The research content is serious and homogeneity. On research objects, Guo Minyuan (2013), Liang Xinju(2010) paid more attention to single province, 
few attention to urban agglomeration and economic zone. While in the long term, urban agglomeration and economic zone are vital parts in developing enclave economy. On research methods, qualitative research has be taken up a large proportion, and there is a lack of quantitative research. Most researchers don't deeply analyze the cooperative and competitive relationship that exist during the construction main bodies (government, enterprise, individual) in enclave economy and strategy selection made by the construction main bodies. But many scholars, such as Guan Xiqiang(2010), Fu Jingtao(2010), analyzed the competitive relationship among different cities by establishing game model, which enlightened other scholars. In many factors that affect enclave economy, the own comparative advantage and preferential policy of government of host city are the most important. Therefore, the economic competitive relation between host cities will be analyzed by building game models with comparative advantage and preferential policy as the variables.

\section{GAME MODEL}

Game theory refers to the processes of strategy selections and earning profits that is implemented by individual or organization under limited conditions and rules depending on the information they have. Game theory is a vital economics conception and it is widely used in politics, economy and people's daily life.

\section{A. Basic hypothesis}

(1) The participators in the game are the host cities (two random cities of one province or economic zone and urban agglomeration in China's central and western regions). Both of the cities are rational-economic men and pursue of the maximum profits.

(2) The comparative advantage and preferential policy of the city are the key factors that generate enclave economy.

(3) All information about comparative advantage is public. The strategy difference on enclave economy between the host cities is divided into preferential policy and no preferential policy.

(4) Developing enclave economy brings certain benefits to the cities. And it will certainly cost offer some preferential policy for enclave economy.

\section{B. The construction of game model}

Assume that a coastal region $\mathrm{Z}$ (investing city) is planning to construct an enclave industrial park in city A and city B (host city). So the attraction of comparative advantage can be divided into two cases: one of the cities has the comparative advantage while the other doesn't; both of the cities don't have comparative advantage. Base on the two cases, the two cities' profits will be discussed in two conditions: cities having preferential policy and cities having no preferential policy.
1) both of the two cities don't have comparative advantage

If city A and city B don't have comparative advantage, government policy become the important factor to develop enclave economy. Assume that both of the two cities' initial profit is 5 units. The city's profit will increase 20 units if it is the place where the industrial park locates. The costs for adopting some preferential policies are 1 units. When city $A$ is able to offer preferential policy while city B isn't, Z will definitely chooses city A as host city. On this occasion, city A's profit will be 24 units, and city B's profit will be 5 units. When the circumstance is contrary, city B will be the host city. And city A's profit will be 5 units, and city B's profit will be 24 units. If city A and city B don't offer preferential policy, the two host cities will gain half of the project and fund respectively, both of the cities' profits will be 15 units. If city A and city B offer preferential policy, both of the cities' profits will be 14 units, which is shown in the following table I.

TABLE I. PROFIT MATRIX OF THE TWO CITIES THAT DON'T HAVE COMPARATIVE ADVANTAGE

\begin{tabular}{|c|c|c|c|}
\hline \multicolumn{2}{|c|}{ Sector } & \multicolumn{2}{c|}{ City B } \\
\cline { 2 - 4 } \multicolumn{2}{|c|}{} & policy & no policy \\
\hline \multirow{2}{*}{ City A } & policy & 14,14 & 24,5 \\
\cline { 2 - 4 } & no policy & 5,24 & 15,15 \\
\hline
\end{tabular}

2) one of the two cities has comparative advantage

Assume that compared with city B, city A has comparative advantage, and then it will lead a different result on host region selection. Since city A has comparative advantage, so it will be the host region even when both of city A and city B are able to offer preferential policy. On this occasion, city A's profit will be 24 units, city B's profit will be 4 . When city A is able to offer preferential policy while city B isn't, the former one will be the host region without doubt. The profit comparison will be: city A (24 units), city Y (5 units). If both of city A and city B aren't able to offer preferential policy, the city with comparative advantage will be chosen as the host region. On that occasion, city A's profit will be 25units, city B's profit will be 5 units. If city A isn't able to offer preferential policy while city B is, the host region selection will depend on the relative effect of comparative advantage and preferential policy. When comparative advantage effect is bigger than preferential policy effect, the city A (with comparative advantage but no preferential policy) will be the host region. The Nash Equilibrium will be no preferential policy, the profit comparison will be: city A (25 units), city Y (4 units), which is presented in the following Table II . 
TABLE II. PROFIT MATRIX OF CITY A THAT HAS COMPARATIVE ADVANTAGE (COMPARATIVE ADVANTAGE EFFECT> PREFERENTIAL POLICY EFFECT)

\begin{tabular}{|c|c|c|c|}
\hline \multicolumn{2}{|c|}{ Sector } & \multicolumn{2}{c|}{ City B (no advantage) } \\
\cline { 2 - 4 } & policy & no policy \\
\hline \multirow{2}{*}{ City A(advantage) } & policy & 24,4 & 24,5 \\
\cline { 2 - 4 } & no policy & 25,4 & 25,5 \\
\hline
\end{tabular}

When comparative advantage effect is smaller than preferential policy, the city B (no comparative advantage but with preferential policy) will be the host region. Thus the profit comparison will be: city A ( 5 units), city B (24 units). There is no Nash Equilibrium existing. The host city selection will depend on the bargaining between investing city and host city, which is presented in the following Table III.

TABLE III. PROFIT MATRIX OF CITY A THAT HAS COMPARATIVE

ADVANTAGE(COMPARATIVE ADVANTAGE EFFECT < PREFERENTIAL POLICY EFFECT)

\begin{tabular}{|c|c|c|c|}
\hline \multicolumn{2}{|c|}{ Sector } & \multicolumn{2}{c|}{ City B (no advantage) } \\
\cline { 2 - 4 } & policy & no policy \\
\hline \multirow{2}{*}{ City A(advantage) } & policy & 24,4 & 24,5 \\
\cline { 2 - 4 } & no policy & 5,24 & 25,5 \\
\hline
\end{tabular}

\section{CONCLUSION}

Through establishing the two cities as the main body as well as taking comparative advantage and preferential policy as the decision variable in the game model, the following results can be obtained:

(1) The two cities' cooperation will lead to higher gross profit when both of the two cities are no comparative advantage. From Table I, the Nash Equilibrium of the game model is (policy, policy), but it is not the optimal strategy. Supposed that city A cooperates with city B, both of who adopt no preferential policy strategy, the corresponding gross profit will be 30 units, which is higher than 28 units when they don't cooperate with each other.

(2) Whether two cities cooperate with each other or not,the optimal solution will always be no policy,it will not make any difference on gross profit in the game model: one of the two cities has comparative advantage.

(3) Since adopting the preferential policy will incur certain cost, the gross profit of a city with comparative advantage will be higher than that of two cities without comparative advantage.

(4) It will get higher profit if one of the two cities has comparative advantage. It can be proved in Table II and table III that both of the two cities' optimal strategies are no preferential policy. It is clear that city A (with comparative advantage) gets higher profit than city $\mathrm{B}$ does. Therefore comparative advantage plays a very significant role in attracting projects and funds.

\section{OPINIONS AND SUGGESTIONS}

With the acceleration of economic globalization and regional economic integration, inter-regional transfer of industry trends become increasingly evident. Many industrial parks with enclave character have been planed and constructed. This provides a good internal and external conditions for enclave economy development in Midwest regions of China. Through the above analysis, the following policy recommendations will be proposed:

\section{A. Establish a rational division of work cooperation} mechanism and avoid over competition or vicious competition caused by all cities are likely to fight over funds and projects

From the above game analysis, it will contribute to achieve the maximization profits of the whole region if there is an active cooperation among cities. It is particularly necessary to establish an effective mechanism for division of responsibilities. First, build a good mutual development platform for regional enclave economy. It includes platforms of investment and public technology, information technology, financing, integrated service and so on. Second, construct the coordination mechanism for regional division of work; make clear about the benefit sharing between regional cooperation; raise the enthusiasm of cooperation.

\section{B. Play the city own strength, build competitive advantage.}

Game analysis shows that comparative advantage plays a crucial role in maximizing the enclave profits. Judging from the development of the cities in Chinese central and west regions, the local economic strength is not strong, the comparative advantage is not prominent and the industrial agglomeration effect is not significant. Therefore, all cities should give full play to their own advantages to form a number of competitive domestic industries as well as extending their industrial chain through industrial transferring. In the meantime, the construction of urban-rural infrastructure and industrial coordination capability should be strengthened to create a good investment environment and improve the integrated competitive power.

C. Break the old fixed thinking, Consider the establishment of a reverse enclave and Overseas enclave economy base

At present, it is common to establish enclave industry park through industry transfer from developed areas to 
less developed areas. While it can be seen from the game analysis that the city with comparative advantage has stronger competitiveness in the development of enclave economy. Therefore, the central and western regions should stand at the overall situation of national regional development strategy, emancipate the mind, discourage the concern of "benefits will spill over", dare to give up local interests, establish the idea of win-win cooperation, actively participate in inter-regional economic cooperation and competition as well. Competitive enterprises should be encouraged to build reverse enclave in eastern coastal regions of China and overseas enclave economy base even around the world. So it will further expand development space and rich content and mode of the enclave economy.

\section{ACKNOWLEDGEMENTS}

This paper is supported by Natural Science Foundation of China (71271162)

\section{REFERENCES}

[1] Min Zhou,Myungduk Cho.Noneconomic Effects of Ethnic Entrepreneurship: A Focused Look at the Chinese and Korean En-clave Economies in Los Angeles[J]. Thunderbird International Business review, 2010, 52(2): 83-96

[2] Kathleen A,Bubinas.An Anthropological Study of the Employment of Asian Immigrants in an Ethnic Enclave Economy[D]. The University of Wisconsin-Milwaukee, 2001.

[3] Edward Iwata.Study Shows Immigrants "a real engine" for Growth: Highly Skilled Entrepreneurs Create "enclave economies" [N]. USA TODAY, McLean, 2007-02-07(B5).
[4] Peter S Li,Chunhong Dong.Earnings of Chinese Immigrants in the Enclave and Mainstream Economy[J]. The Canadian Re-view of Sociology and Anthropology, 2004,44(1): 415-418

[5] Heike Christine Alberts. Rethinking the Ethnic Enclave Economy: Cubans in Miami[D]. University of Minnesota, 2003.

[6] Joseph E Mbaiwa. Enclave Tourism and Its Socio-Economic Impacts in the Okavango Delta,Botswana[J]. Tourism Management, 2005,26(2): 157-172.

[7] Kevin P Gallagher, Lyuba Zarsky. The Enclave Economy: Foreign Investment and Sustainable Development in Mexico's Silicon Valley[M]. Massachusetts: MIT Press, 2007.

[8] Li Junyang, Xia Huifang. Research on Pattern of "enclave economy" in Development Zone[J]. Business Economics and Administration, 2006(2): 55-60

[9] Feng Yunting. Study on the Enclave Economy Pattern and the Mutual Benefit Mechanism[J]. Research on Financial and Economic Issues, 2013(7): 94-102

[10] Li Yu. Research on Pattern of enclave economy[J]. Scientific and Technological Information, 2007(31): 451

[11] Mao Baobin, Du Ping. Research on Enclave Economy Management in Regional Economic Cooperation[J]. Journal of Tianjin Administration Institute. 2014(2): 71-79

[12] Guo Minyua. Progress of Enclave Economy Cooperation and Tianjin Choice[J]. Development Study. 2013, (9):18-22

[13] Liang Xinju. Study on enclave economy construction with Undertaking industrial transfer: Taking Xuancheng City as the example[J]. knowledge economy, 2010(3): 179-180

[14] Guan Xiqiang, Ouyang Hua. The Game Model about City Integrates Coordination in Guangxi Beibu Gulf Economic Zone[J]. Urban Studies, 2010(9): 41-46

[15] Fu Jingtao. Research on Cooperative Game of Construction Main Body of Two-Orient Society-in Changsha Zhuzhou Xiangtan city group as an example[J]. Inquiry into Economic Issues, 2010(9): $157-161$. 